\title{
The first sighting of Longman's beaked whale, Indopacetus pacificus in the southern Bay of Bengal
}

\author{
V.V. AFSAL, P.P. MANOJKUMAR, K.S.S.M. YOUSUF, B. ANOOP AND E. VIVEKANANDAN \\ Central Marine Fisheries Research Institute, Kochi, Kerala, India - 682018
}

\begin{abstract}
Information on at-sea sightings of beaked wholes are rare from the Indian and Sri-Lankan waters because of the relative rarity of vessels working in deep oceans where these species are encountered. A recent survey onboard FORV 'Sagar Sampada' brought out the first confirmed sighting of live animals of Longman's beaked whole. Indopacetus pacificus from the southern Bay of Bengal. The details of the sighting, illustrated with photographs are presented in this note.
\end{abstract}

Keywords: Longman's beaked whale, Bay of Bengal

Submitted 17 March 2009; accepted 25 May 2009

Indopacetus pacificus, Longman's beaked whale (also known as Indo-Pacific beaked whale or tropical bottlenose whale), is an uncommon or rare ziphiid restricted to warmer waters of the Indian and Pacific Oceans. Until recently it was one of the least known species among living toothed whales, and only vague information was available on its field characteristics. But after the publications of Pitman et al. (1999) and Dalebout et al. (2003), I. pacificus became one of the more frequently identified beaked whales. Before 2003 there were no confirmed live sightings in the wild. Since then, however, there have been at least eight new stranding records and at least 65 at-sea sightings from the world's oceans (Pitman, 2008). From the western and central tropical Indian Ocean, Anderson et al. (2006) have listed 32 records, of which five were from Sri Lanka. This note reports an at-sea sighting of I. pacificus in the southern Bay of Bengal.

A series of opportunistic surveys were conducted aboard the Fisheries and Oceanographic Research Vessel 'Sagar Sampada' (overall length: $71.4 \mathrm{~m}$ ) to study the distribution and diversity of cetaceans in the Indian EEZ and contiguous seas. A single observer, equipped with a Nikon $10 \times 50 \mathrm{~mm}$ CFWP hand-held binocular and a Nikon D8o camera fitted with Nikor 70-300 mm lens, collected data during daylight hours. The sighted animals were identified at the time of observation or subsequently with the help of photographs and field notes. The species identifications were confirmed with the aid of the field guide Marine Mammals of the World (Jefferson et al., 2007) and other published materials.

On 28 January 2009 at $1330 \mathrm{~h}$, during a recent marine mammal survey cruise from the south-eastern Arabian Sea to the Andaman Sea, we sighted a group of Longman's beaked whales in the southern Bay of Bengal at the position of $6^{\circ} 18^{\prime} \mathrm{N} 85^{\circ} 50^{\prime} \mathrm{E}$ (Figure 1). The location of the sighting

Corresponding author:

V.V. Afsal

Email:vafsal@gmail.com was about 220 nautical miles away from south-east coast of Sri Lanka at a water depth of $3500 \mathrm{~m}$. The sea surface temperature was $28.6^{\circ} \mathrm{C}$, which is well within the range (i.e. $21-31^{\circ} \mathrm{C}$ ) recorded for the species (Pitman et al., 1999). The whales showed no reaction to the vessel as we passed within $100 \mathrm{~m}$ of them; we were in passing mode survey and unable to approach them. No associated animals were observed. The sea condition was Beaufort force 4 with good visibility.

The animals were identified as Indopacetus pacificus (Longman, 1926) based on its large size, bulbous melon with distinct beak, and the pale colour of the melon that extended only as far back as the blowhole (Figure $2 \mathrm{~A}-\mathrm{F}$ ). This differentiates the species from similar-looking Hyperoodon spp. in which the paleness on the melon extends posterior to the blowhole (Pitman, 2008). Circular and linear scars were visible in some individuals, the former probably due to cookie-cutter shark (Isistius spp.) bites. The apparent body colour of individuals can vary depending upon age, sex and weather conditions (Pitman et al., 1999; Anderson et al., 2006). The dorsal fin was located behind the midpoint of the body and was relatively tall, pointed and slightly falcate with a long base; this species has a noticeably large dorsal fin (Pitman et al., 1999; Jefferson et al., 2007). The 'blow' appeared low and bushy and slightly canted forward, features also mentioned by Pitman et al. (1999) and Anderson et al. (2006).

The group consisted of five whales with approximate body length ranging from 5 to $6 \mathrm{~m}$. The mean group size recorded for the species from the western tropical Indian Ocean was 7.2 (Anderson et al., 2006). It could be determined from the body lengths that the group consisted of adults and sub-adults, as the maximum recorded adult length of this species is $6.5 \mathrm{~m}$ (Pitman, 2008).

According to Anouk Ilangakoon (personal communication) there were six records of the Longman's beaked whale from Sri Lanka. The first record was of a stranded animal near Colombo harbour (west coast of Sri Lanka) in 1939. Alling (1986) reported two unconfirmed sightings of Hyperoodon planifrons (southern bottlenose whale) off the 


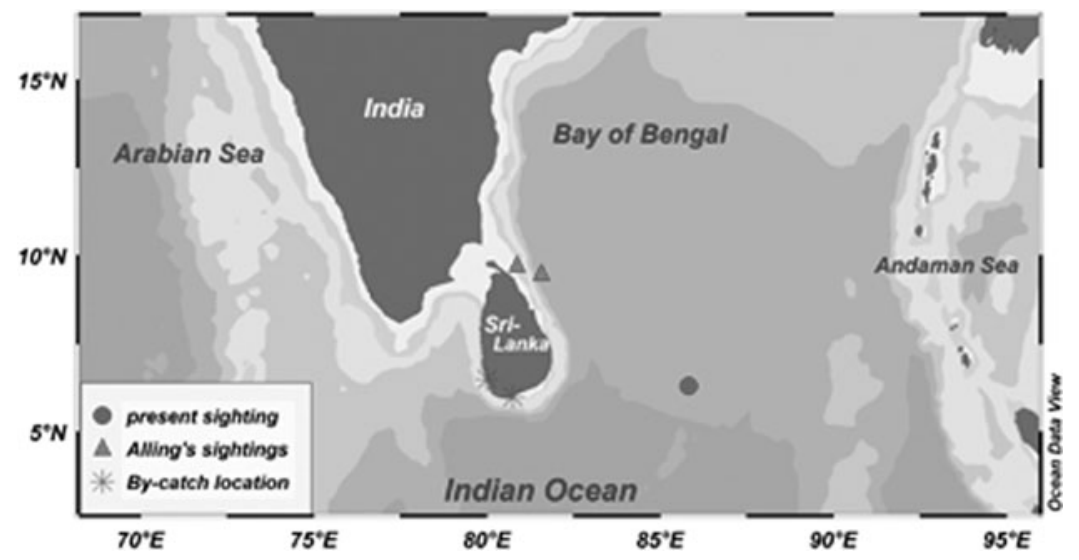

Fig. 1. Map showing the locations of Longman's beaked whales' records from Sri Lanka and the southern Bay of Bengal.

east coast of Sri Lanka during the voyage of the 'Tulip'. But later Pitman et al. (1999), on detailed analysis, suggested that the cetacean could be Indopacetus pacificus. The other three records were from by-catch in gill-nets, two from the south-west coast and one from the south coast of Sri Lanka during a by-catch survey in 1991/1992 (Dayaratne \& Joseph, 1993). There is no record for the Indian coasts. Complementing the previous information, ours is the first
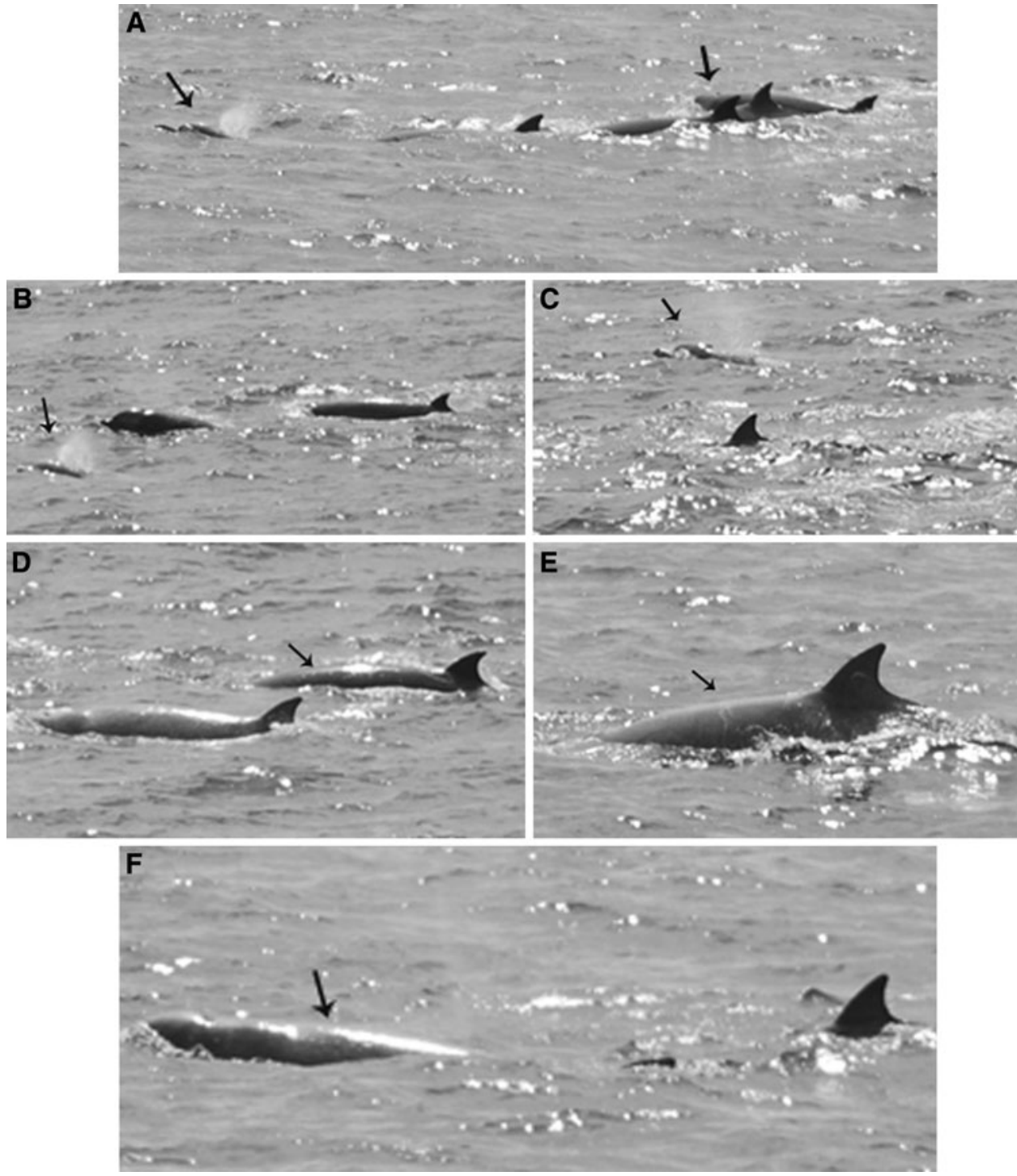

Fig. 2. (A-F) Longman's beaked whales from the southern Bay of Bengal, 28 January 2009 (arrows highlight the distinctive features observed). 
confirmed sighting record, illustrated with photographs, for wild animals of this species for the southern Bay of Bengal.

The waters off Sri Lanka and India are rich in cetacean diversity and abundance with 27 species recorded so far from Sri Lanka (Ilangakoon, 2006) and 25 species from India (Kumaran, 2002). With seasonally changing blooms of plankton supporting food chains and with deep water so close to the shore, the southern Sri Lankan waters appear to be a cetacean hotspot. More dedicated surveys in the area can definitely bring out very interesting sightings.

\section{ACKNDWLEDGEMENTS}

The authors thank R.L. Pitman, Anouk Ilangakoon and R.R. Reeves for confirming the species identity. We also thank the Ministry of Earth Science, the Government of India and the Central Marine Fisheries Research Institute for support and facilities. The support from the crew of FORV 'Sagar Sampada' and our colleagues is greatly appreciated.

\section{REFERENCES}

Alling A. (1986) Records of odontocetes in the northern Indian Ocean $(1981-1982)$ and off the coast of Sri Lanka (1982-1984). Journal of the Bombay Natural History Society 83, 376-394.

Anderson R.C., Clark R., Madsen P.T., Johnson C., Kiszka J. and Breysse O. (2006) Observations of Longman's Beaked Whale (Indopacetus pacificus) in the Western Indian Ocean. Aquatic Mammals 32, 223-231.
Dayaratne P. and Joseph L. (1993) A study on dolphin catches in Sri Lanka. Report of the Bay of Bengal Programme, Madras, BOBP/REP/ 56, 43 pp.

Ilangakoon A.D. (2006) Taxonomy and current status of marine mammals in Sri Lanka. In Bambaradeniya C.N.B. (ed.) The fauna in Sri Lanka: status of taxonomy, research and conservation. Colombo, Sri Lanka: The World Conservation Union, pp. 302-307.

Jefferson T.A., Webber M.A. and Pitman R.L. (2007) Marine mammals of the world: a comprehensive guide to their identification. London: Academic Press.

Kumaran P.L. (2002) Marine mammal research in India-a review and critique of the methods. Current Science 83, 1210-1220.

Pitman R.L. (2008) Indo-Pacific beaked whale-Indopacetus pacificus. In Perrin W.F. (eds.) Encyclopedia of marine mammals. 2nd edition. San Diego, California: Academic Press, pp. 600-602.

and

Pitman R.L., Palacios D.M., Brennan P.L.R., Brennan B.J., Balcomb K.C. and Miyashita T. (1999) Sightings and possible identity of a bottlenose whale in the tropical Indo-Pacific: Indopacetus pacificus? Marine Mammal Science 15, 531-549.

\section{Correspondence should be addressed to:}

V.V. Afsal

Central Marine Fisheries Research Institute

Kochi, Kerala

India -682018

email: vafsal@gmail.com 